\title{
Avaliação Institucional: a Universidade
}

\section{Texto proposta para uma discussão}

A avaliação no campo da educação até dias recentes ficou centrada no alunọ e no rendimento escolar, resultante do processo de orientação da aprendizagem. A partir dos anos 50 , em diferentes contextos educacionais, o campo da avaliação expandiu-se, envolvendo currículos, programas e material instrucional. A complexidade do processo educacional exigiu que outras variáveis integrassem o campo da avaliação, a fim de melhor analisar e compreender a-influência da educação sobre o homem e a sociedade. Assim, a avaliação passou a preocupar-se com instituiçöes (escola/universidade) e com o próprio sistema em suas diferentes dimensōes.

A universidade, em virtude de sua importância em uma sociedade democrática e pluralista, como responsável pela criação e difusảo de conhecimentos, por intermédio do processo educacional, ao mesmo tempo que geradora do desenvolvimento científico e tecnológico, por suas atividades de pesquisa, passou a sofrer maiores exigências do corpo social em termos de cficiência e eficácia. Os problemas da universidade revestem-se de grande complexidade e resultam da integração de inúmeras variáveis, impondo-se, assim, um constante acompanhamento de suas múltiplas atividades com base em pesquisa de avaliação, que, entretanto, gera receios, sobrctudo no que diz respeito ao comprometimento de sua autonomia. A autonomia universitária, ao contrário, afirma-se na medida em que é possfvel conhecer o desenrolar das atividades da universidade, por intermédio da avaliação, e, dessa forma, aumentar a sua credibilidade pública.

A avaliação da universidade precisa definir seus objetivos e delimitar com precisão suas áreas de interesse; por outro lado, em face da complexidade da avaliação institucional, necessita estabelecer prioridades. Algumas dicisöes cruciais deverão ser tomadas em relação à auto-avaliação, à avaliação interna e à avaliação externa; no entanto, mesmo antes de definidos parâmetros de avaliação, respostas deverão ser dadas a algumas indagações: a quem cabe avaliar a universidade? Qual o perfil do avaliador e quais as suas precisas responsabilidades? Qual a formação desejável de um avaliador universitário?

Os problemas metodológicos em avaliação institucional, sobretudo no campo da universidade, revestem-se de grande complexidade, como, aliás, toda e qualquer atividade de avaliação. Existe grande diversidade de modelos na avaliação de universidades, impondo-se, pois, a seleçåo do mais adequado às particularidades do trabalho. $O$ crítico em avaliação institucional está na seleção de diferentes indicadores para análise das variáveis 
que interagem no contexto institucional e social. Culminando a tudo isso hâ, ainda, o problema da validaçäo das normas de avaliação, a fim de apresentar resultados que igualmente se revistam de validade.

A universidade procura atender a uma demanda social, inclusive em relação ao mercado de trabalho, dessa forma, impöe-se saber até que ponto as expectativas da sociedade estão sendo atendidas. Isso somente é possível através da avaliação institucional, que tambem procura avaliar se a universidade oferece diversas oportunidades de estudos por áreas de conhecimentos e qual o grau de sua eficiência na formaçäo de recursos humanos qualificador. As dimensões pesquisa cientffica e desenvolvimento da tecnologia integram a avaliação institucional de universidades, que se completa na medida em que seus currículos, seus programas de ensino, seus professores e a qualidade do ensino, da pesquisa e da extensão são igualmente avaliados.

A avaliação não se esgota ao completar esse quadro. Exige, ainda, a avaliação de seus custos operacionais e da alocação de recursos por diferentes fontes para a instituição, cm função do estabelecimento de sua eficiência interna e externa. A universidade existe em um contexto de interrelações e reflete em suas atividades princípios definidos pelas políticas públicas; assim, é necessário, também, avaliar as relaçōes MEC/CFE e IES. Ao término, a avaliação precisa preocupar-se com a meta-avaliação, ou, em outros termos, avaliar a própria avaliação.

O trabalho de avaliação institucional resulta de um esforço cooperativo, que, no caso da avaliação de universidades, implica o trabalho de alunos, administradores, professores e da propria sociedade, sob, naturalmente, a coordenaçäo de um avaliador; entretanto, tendo em vista a complexidade do seu trabalho, restam as perguntas: qual o seu perfil? Qual a sua formaçảo? Quais as experiências que deve possuir? Quais os procedimentos para criar individuos capacitados nessa área? (H.M. VIANNA). 